\title{
Application of Bacillus coagulans in Animal Husbandry and Its Underlying Mechanisms
}

\author{
Yuanhao Zhou ${ }^{1}$, Zihan Zeng ${ }^{1}$, Yibin Xu ${ }^{1}$, Jiafu Ying ${ }^{1}$, Baikui Wang ${ }^{1}$, Muhammed Majeed ${ }^{2,3,4}$, \\ Shaheen Majeed ${ }^{3,4} \oplus$, Anurag Pande ${ }^{3}$ and Weifen $\mathrm{Li}^{1, *}$ \\ 1 Key Laboratory of Molecular Animal Nutrition of the Ministry of Education, Institute of Feed Science, \\ College of Animal Sciences, Zhejiang University, Hangzhou 310058, China; zyh17767072477@163.com (Y.Z.); \\ 21817016@zju.edu.cn (Z.Z.); 21817002@zju.edu.cn (Y.X.); 21817401@zju.edu.cn (J.Y.); \\ wangbaikui@zju.edu.cn (B.W.) \\ 2 Sami Labs Limited, Bangalore, Karnataka 560058, India; mail1@samilabs.com \\ 3 Sabinsa Corporation, East Windsor, NJ 08520, USA; shaheen@sabinsa.com (S.M.); anurag@sabinsa.com (A.P.) \\ 4 Sabinsa Corporation, Payson, UT 84651, USA \\ * Correspondence: wfli@zju.edu.cn; Tel.: +86-13107728728
}

Received: 8 February 2020; Accepted: 2 March 2020; Published: 9 March 2020

Simple Summary: Probiotics, a kind of feed additive, are widely used in animal husbandry and the effects are quite positive. Many strains of Bacillus spp. are currently used as probiotic dietary supplements in animal feeds. Bacillus coagulans, a probiotic with good application prospects, piqued our strong interest. In this review, information on Bacillus coagulans in scientific research and production practices is summarized.

\begin{abstract}
In recent decades, probiotics have attracted widespread attention and their application in healthcare and animal husbandry has been promising. Among many probiotics, Bacillus coagulans (B. coagulans) has become a key player in the field of probiotics in recent years. It has been demonstrated to be involved in regulating the balance of the intestinal microbiota, promoting metabolism and utilization of nutrients, improving immunity, and more importantly, it also has good industrial properties such as high temperature resistance, acid resistance, bile resistance, and the like. This review highlights the effects of B. coagulans in animal husbandry and its underlying mechanisms.
\end{abstract}

Keywords: Bacillus coagulans; probiotics; nutrient metabolism; immunomodulation; antioxidant

\section{Introduction}

Probiotics are defined as "live microorganisms that, when administered in adequate amounts, confer a health benefit on the host" [1]. Furthermore, microorganisms that can be classified as probiotics should meet the following requirements: (1) to survive in the gastrointestinal environment, that is, to be acid and bile resistant; (2) to adhere to intestinal epithelial cells; (3) to grow rapidly, colonize the intestinal tract, to persist there and then leave the hosts; (4) to stabilize the intestinal microbiota; (5) to have no signs of pathogenicity; and (6) to maintain vitality both in food and pharmaceutical processes [2,3]. Probiotics have attracted more and more interest from animal nutritionists and livestock producers owing to their benefits to the gastrointestinal tract [4], and their role as one of the best alternatives to antibiotics in animals including poultry and fish [5]. Probiotics possess the function of promoting growth [6] and can be used as growth enhancers [7]. In addition, numerous studies have shown that probiotics have antimicrobial activity [8-10], which allows their consideration as alternatives to antibiotics. Probiotics could prevent or inhibit the proliferation of pathogens, suppress the production of virulence factors and perform beneficial functions as biofilms [11]. 
There are several types of probiotics used in the food sector, medical care and animal husbandry, such as Lactobacillus, Bifidobacterium, Bacillus subtilis, and others. Among them, Lactobacillus and Bifidobacterium are the most commonly used probiotic preparations [12]. However, the majority of these strains are not resistant to extreme temperatures, as well as stomach acid, digestive enzymes and bile salts [13]. Moreover, it is necessary to characterize other types of probiotics because of the technological difficulties with the delivery mechanism with the use of Lactobacillus and Bifidobacterium. Due to the non-sporulating characteristic of these genera, freeze drying is required, which, in turn, reduces the shelf life of powdered probiotic preparations and adversely affects their viability [14].

It is worth pointing out that many strains of Bacillus spp. are currently used as probiotic dietary supplements [15]. One of the reasons is that spore-forming probiotics are highly resistant to extreme environmental conditions [16]. Bacillus spp. have a higher acid tolerance and better stability in the process of heat treatment and low temperature storage compared to other probiotics [17]. Bacillus coagulans (B. coagulans) is a Gram-positive, facultative anaerobic, nonpathogenic, spore-forming and lactic acid-producing bacterium [18]. It is known as 'the king of probiotics' due to its high stability in the gastrointestinal tract, non-toxic effects, as well as high but not yet fully understood pharmacological activity [19]. B. coagulans is resistant to temperature; the perfect growth temperature for B. coagulans is 35 to $50^{\circ} \mathrm{C}$ and the optimum growth $\mathrm{pH}$ is 5.5 to 6.5 [18,20]. Furthermore, spores of B. coagulans possess strong resistance, revival and stability, which can be activated in the acidic environment of the stomach and begin to germinate and proliferate in the intestinal tract [21]. Spores can accommodate to the intestinal low oxygen environment and reach the gastrointestinal tract smoothly so as to play the role of lactic acid bacteria (LAB) in the intestinal tract [21]. It has been found that the survival of the spores of B. coagulans during simulated digestion is $92 \%$ [22]. Once germinated, B. coagulans could produce a bacteriocin called coagulin, which has activity against a broad spectrum of enteric microbes [23], which is one of the mechanisms for B. coagulans to exert antibacterial activity. The factors previously listed confer $B$. coagulans many advantages over other LAB strains. It is worth pointing out that $B$. coagulans lacks the ability to adhere to the intestinal epithelium unless long-term administration is maintained. B. coagulans will be completely eliminated in four to five days [24]. Owing to this characteristic, B. coagulans may need long-term administration in order to play the role of a probiotic. For example, it has been shown that, B. coagulans spores, when administered at a level of $10^{9}$ spores/day for 30 days, could affect the intestinal microbiota of rats [25].

The discovery of B. coagulans dates back to 1915, when it was first found in curdled canned evaporated milk. It was described by the Iowa Agricultural Experiment Station [26], and isolated for the first time in 1932 [27]. At the beginning of the discovery, B. coagulans was known as Lactobacillus sporogenes and considered as a promising probiotic candidate, possessing the common characteristics of both Bacillaceae and Lactobacillaceae [28]. Nowadays, there are several strains of B. coagulans that have been used in animal feeds and research, such as B. coagulans ATCC 7050 [21] and commercial strains like B. coagulans MTCC5856 [29]. The application of B. coagulans in commercial feed and pet supplements has been supported by the stability in processed food [30] as well as phenotypic and genetic consistency for this strain [29]. Moreover, the safe application of B. coagulans has been supported by a toxicological safety assessment by Endres and colleagues [31]. They proved that B. coagulans is safe after conducting a one-year chronic oral toxicity study combined with a one-generation reproduction study [32].

\section{The Application of B. coagulans in Animal Husbandry}

Many studies have shown that the application of B. coagulans obtained good results in animal husbandry. For example, $B$. coagulans could decrease the diarrhea rate and improve the growth performance of piglets [33]. In addition, $B$. coagulans has been used widely in poultry production. It is well worth mentioning that B. coagulans has a growth-promoting effect on broiler chickens [34], possibly via improving the balance of intestinal microbiota to improve the feed conversion ratio [21]. Furthermore, B. coagulans not only displays a growth promoting effect in broilers, but also increases the activities of protease and amylase [35]. We know that protease and amylase play a crucial role in 
the fermentation of relative nutrients [35]. As for local chickens, such as the Guangxi Yellow chicken, the supplementation of $B$. coagulans could improve their growth performance and showed positive effects on meat quality [36]. Moreover, probiotics are also widely used in aquaculture. For example, B. coagulans could significantly improve the final weight, daily weight gain and relative weight gain of the shrimp [37]. In addition, a diet supplemented with B. coagulans had similar effects on a grass carp [38].

\section{B. coagulans Promotes Nutrient Metabolism}

One of the most beneficial effects of probiotics is that they could produce a large number of active enzymes in the process of metabolism and promote the absorption of nutrients to improve the feeding conversion efficiency. Secondly, probiotics could promote the synthesis and metabolism of proteins, vitamins and short chain fatty acids [39-41]. These metabolites exert many positive effects on energy metabolism.

$B$. coagulans could help digest carbohydrates and proteins once they are activated and germinated [42]. B. coagulans could improve growth performance and increase feed digestibility via producing amino acids and vitamins and secreting a-amylase, xylanase, protease and lipidase [34]. Furthermore, consumption of $B$. coagulans creates a healthy and efficient intestinal environment [43]. For example, when birds were fed a diet with B. coagulans, even though they were infected by Salmonella enteritidis later, their average body weight gain and the feed conversion ratio during the initial stage could still be improved [6]. Such a beneficial effect is probably owed to the promoted secretion of endogenous enzymes which improves the nutrient digestibility [35]. Moreover, B. coagulans also produces some exogenous enzymes and unknown growth-promoting factors which could increase the intestinal peristalsis and the feed digestibility [44,45]. B. coagulans produces $\alpha$-galactosidase which strongly resists hydrolysis by protease [46]. $\alpha$-galactosidase is an enzyme which catalyzes the removal of terminal nonreducing galactose residues from different substrates [46]. However, it is worth identifying which factor plays an important role in this nutrient metabolism process. In addition, it has been found that $B$. coagulans could decrease inflammation, resulting in the development of the absorptive area of the villi and the enhancement of nutrient absorption [47].

Probiotics offer numerous health benefits, including digestive health. Improving digestive health is associated with the more efficient absorption of crucial nutrients from the diet [48]. B. coagulans could help liberate digestion products, which are shorter peptides and more free amino acids than those produced by the control group, an in vitro model lacking probiotics [49]. In addition, B. coagulans also improves protein absorption and maximizes health benefits [48]. B. coagulans could promote nutrient metabolism via increasing the expression levels of genes related to nutrient absorption and transportation [33]. Prebiotics are defined as "non-absorbable food components that beneficially stimulate one or more of the gut-beneficial microbe groups and thus have a positive effect on human health" [50]. Probiotics have a cooperative phenomenon with prebiotics. B. coagulans could ferment with galactomannan, a kind of prebiotic, and produce short chain fatty acids, lactic acid and other compounds to play an important role in modulating intestinal microbiota [51]. In addition, B. coagulans could increase the population of beneficial bacteria to increase the benefits of prebiotics [52].

\section{B. coagulans Regulates Immune Function}

The gastrointestinal system is closely connected with the immune system [53]. The immune system identifies whether substances are harmless or potentially deleterious at the interface between the lamina propria and the enteric cavity [54]. Oral probiotics interact with gastrointestinal (GI) mucosa and gut associated lymphoid tissue (GALT) where more than 70\% of immune cells are located [55]. Probiotics possess the power to influence the innate and adaptive immune system by interacting with several types of immunological cells such as B cells, $\mathrm{T}$ cells, regulatory $\mathrm{T}$ cells, dendritic cells, natural killer cells, monocytes and macrophages along the mucosa $[56,57]$. There are several types of 
interactions between intestinal microorganisms and the host cells and tissues, including via bacterial cell wall components and secreted metabolites [58].

B. coagulans could modulate an immune system, stimulate the rapid recovery of normal intestinal microbiota and possess antiviral activity [59]. B. coagulans could affect the intestinal microbiota through transient proliferation in intestines [25]. It could modify the ecology of gastrointestinal microorganisms by supplementing the quantity of the desirable obligate microorganisms and antagonizing pathogenic microorganisms in pigs [1]. In the matter of reaction with the immune system, the immunomodulatory function of $B$. coagulans is closely interrelated with cytokines. It has been found that when human blood cells are exposed to viruses, such as adenovirus and influenza A, B. coagulans treatment could significantly increase the production of cytokines, such as interleukins(IL-6, IL-8), tumor necrosis factor(TNF- $\alpha$ ), and interferon(IFN- $\gamma$ ) [47]. B. coagulans exhibits an immunomodulatory effect by reducing IL-8 and increasing IL-10 secretion and it could also modulate the immune system to resist the inflammation caused by lipopolysaccharide [22]. As for the application in animal husbandry, the continuous addition of $B$. coagulans helps to reduce the host immune inflammatory response induced by Salmonella enteritidis [6]. These results indicate that $B$. coagulans is crucial for inducing both inflammatory mediators and anti-inflammatory cytokines, which could help the immune system to protect the host against infections and minimize inflammation-related tissue injury.

As for primary mechanisms of immunomodulation, there are two potential factors in this process. On the one hand, the most direct interaction between microorganisms and the host's cells are the components of outer layers of bacterial cell wall and the receptors on immune cells [58]. The receptors could interact with lipopolysaccharide, flagellin, lipoteichoic acid and lipoproteins, which are present on the exterior surface of bacteria [54]. In addition, toll-like receptors (TLR) play an important role against pathogens via activating the transcription factor NF- $\mathrm{KB}$ signaling pathway and inducing inflammatory cytokines, such as TNF- $\alpha$, IL-6, IL-1 $\beta$, IL-8, and IL-12, IFN and co-stimulatory molecules [60]. Gram-positive bacteria, such as B. coagulans, could combine with the TLR-2 receptor via the teichoic acid and lipoteichoic acid [61], and the chemical composition of the bacterial cell wall plays an important role in regulating immune function [58]. It is worth mentioning that the teichoic acid of B. coagulans, which is a glycerophosphate polymer, substituted with glucose and galactose but lacking amino acid substituents, contains a higher lipid content than the majority of Gram-positive bacteria [62]. In this way, B. coagulans possesses the ability to trigger complex beneficial immune reactions [63]. In a study by Jensen et al. [58], they tried to figure out whether the inactivated B. coagulans possesses immune activating and anti-inflammatory functions or not, and they finally demonstrated that it could activate immune cells and alter the production of chemokines and cytokines. Through this research, we conclude that the components of bacterial cell walls are crucial for immunomodulation. On the other hand, epithelial cells play a crucial role in assimilating nutrients and forming a mucosal barrier which could protect tissue from damage [64]. Probiotics could stimulate the mucosal defense to produce antimicrobial peptides [65]. In addition, commensal bacteria could modulate the immune system via secreting certain bioactive compounds, which possess unique health benefits for the host. Benson and colleagues [66] found that the maturation of antigen-presenting cells could be supported by metabolites of $B$. coagulans in vitro. In addition, the metabolites of $B$. coagulans possess strong immune modulating properties and anti-inflammatory effects in vitro [54]. These research studies suggest that B. coagulans may exert its effects by secreting certain bioactive compounds to modulate the immune system.

\section{B. coagulans Possesses Antioxidant Ability and Alleviates the Toxicity of Heavy Metals}

The intestinal microbiota plays a crucial role in protecting its host from pathogenic microbes via occupying adhesion sites, producing antibacterial substances and consuming nutrients [67]. When the intestinal microbiota becomes abnormal, harmful microorganisms proliferate excessively and eventually cause significant oxidative stress [68]. Oxidative stress means that the intracellular levels of oxygen radicals increase, resulting in damage to lipids, proteins, and DNA [69], and it is related to many pathological conditions, as well as the increased levels of reactive oxygen species (ROS) and lipid 
peroxidation [70,71]. The production of high-level free radicals in the intestine will exert cytotoxic effects on the membrane phospholipids of the intestinal epithelial cells [72].

Probiotics could produce different kinds of antioxidative metabolites, such as glutathione (GSH), butyrate, and folate [73]. In addition, probiotics are important factors which affect the oxidative status of the intestine via exhibiting direct antioxidant properties and inducing the intrinsic human signaling antioxidant defense $[72,74]$. B. coagulans could alleviate the oxidative stress via increasing the activities of myeloperoxidase (MPO) and anti-superoxide anion free radical (AFASER), decreasing the content of malondialdehyde (MDA), regulating the transcriptional regulation levels of antioxidant enzymes and Nrf2-Keap1 signaling molecules [75].

Numerous studies pointed out that several types of heavy metals, such as cadmium and mercury, caused oxidative stress via inducing the production of ROS [76,77]. One of the most important reasons is that heavy metals influence some key enzymes of the antioxidant system, like superoxide dismutase (SOD) [78]. Several probiotics which belong to Gram-positive bacteria could release this oxidative stress by binding heavy metals. Bacillus spp. possess a high absorptive capacity owing to the high content of peptidoglycan and teichoic acid of their bacterial cell walls [79]. B. coagulans could protect the host from the oxidative stress caused by mercury [76]. Research into acute cadmium toxicity treated with synbiotics (consisting of B. coagulans, Lactobacillus plantarum and inulin) resulted in increased activity of antioxidant enzymes and a reduced level of cadmium in the tissues [77]. The antioxidant property of $B$. coagulans could be used in animal husbandry to prevent heavy metal poisoning.

\section{Conclusions}

B. coagulans is a spore-forming and lactic acid-producing bacterium which possesses the capacity to improve the feed conversion ratio and the balance of intestinal microbiota, ultimately improving the growth performance of animals. It may also regulate immune function, help the immune system to protect against infections and minimize inflammation-related tissue injury. In addition, B. coagulans possesses antioxidant ability and alleviates the toxicity of heavy metals. Thus, B. coagulans plays a crucial role as a microbial agent and has a beneficial role as a feed additive. The mechanism of the effects of $B$. coagulans in animal husbandry warrants further investigation.

Author Contributions: Design, W.L.; writing—original draft preparation, Y.Z.; revision, the rest of the authors. All authors have read and agreed to the published version of the manuscript.

Funding: Cooperative project funded by Sabinsa company.

Conflicts of Interest: The authors declare no conflict of interest.

\section{References}

1. Adami, A.; Cavazzoni, V. Occurrence of selected bacterial groups in the faeces of piglets fed with Bacillus coagulans as probiotic. J. Basic Microbiol. 1999, 39, 3-9. [CrossRef]

2. Gibson, G.R.; Roberfroid, M.B. Dietary modulation of the human colonic microbiota: Introducing the concept of prebiotics. J. Nutr. 1995, 125, 1401-1412. [CrossRef]

3. Fuller, R.; Gibson, G.R. Probiotics and prebiotics: Microflora management for improved gut health. Clin. Microbiol. Infect. 1998, 4, 477-480. [CrossRef]

4. Dai, Z.L.; Wu, G.; Zhu, W.Y. Amino acid metabolism in intestinal bacteria: Links between gut ecology and host health. Front. Biosci. (Landmark Ed) 2011, 16, 1768-1786. [CrossRef] [PubMed]

5. Zorriehzahra, M.J.; Delshad, S.T.; Adel, M.; Tiwari, R.; Karthik, K.; Dhama, K.; Dhama, K.; Lazado, C.C. Probiotics as beneficial microbes in aquaculture: An update on their multiple modes of action: A review. Vet. Q. 2016, 36, 228-241. [CrossRef]

6. Zhen, W.; Shao, Y.; Gong, X.; Wu, Y.; Geng, Y.; Wang, Z.; Guo, Y. Effect of dietary Bacillus coagulans supplementation on growth performance and immune responses of broiler chickens challenged by Salmonella enteritidis. Poult. Sci. 2018, 97, 2654-2666. [CrossRef] 
7. Alagawany, M.; Abd El-Hack, M.E.; Farag, M.R.; Sachan, S.; Karthik, K.; Dhama, K. The use of probiotics as eco-friendly alternatives for antibiotics in poultry nutrition. Environ. Sci. Pollut. Res. 2018, 25, 10611-10618. [CrossRef] [PubMed]

8. Forestier, C.; De Champs, C.; Vatoux, C.; Joly, B. Probiotic activities of Lactobacillus casei rhamnosus: In vitro adherence to intestinal cells and antimicrobial properties. Res. Microbiol. 2001, 152, 167-173. [CrossRef]

9. Pieniz, S.; Andreazza, R.; Anghinoni, T.; Camargo, F.; Brandelli, A. Probiotic potential, antimicrobial and antioxidant activities of Enterococcus durans strain LAB18s. Food Control 2014, 37, 251-256. [CrossRef]

10. Shokryazdan, P.; Sieo, C.C.; Kalavathy, R.; Liang, J.B.; Alitheen, N.B.; Faseleh Jahromi, M.; Ho, Y.W. Probiotic Potential of Lactobacillus Strains with Antimicrobial Activity against Some Human Pathogenic Strains. Biomed. Res. Int. 2014, 2014, 1-16. [CrossRef]

11. Jones, S.E.; Versalovic, J. Probiotic Lactobacillus reuteri biofilms produce antimicrobial and anti-inflammatory factors. BMC Microbiol. 2009, 9, 35. [CrossRef] [PubMed]

12. Siezen, R.J.; Wilson, G. Probiotics genomics. Microb. Biotechnol. 2010, 3, 1-9. [CrossRef] [PubMed]

13. Ruiz, L.; Ruas-Madiedo, P.; Gueimonde, M.; de Los Reyes-Gavilán, C.G.; Margolles, A.; Sánchez, B. How do bifidobacteria counteract environmental challenges? Mechanisms involved and physiological consequences. Genes Nutr. 2011, 6, 307-318. [CrossRef] [PubMed]

14. Govender, M.; Choonara, Y.E.; Kumar, P.; du Toit, L.C.; van Vuuren, S.; Pillay, V. A Review of the Advancements in Probiotic Delivery: Conventional vs. Non-conventional Formulations for Intestinal Flora Supplementation. AAPS PharmSciTech 2014, 15, 29-43. [PubMed]

15. Mingmongkolchai, S.; Panbangred, W. Bacillus probiotics: An alternative to antibiotics for livestock production. J. Appl. Microbiol. 2018, 124, 1334-1346. [CrossRef] [PubMed]

16. Kapse, N.G.; Engineer, A.S.; Gowdaman, V.; Wagh, S.; Dhakephalkar, P.K. Functional annotation of the genome unravels probiotic potential of Bacillus coagulans HS243. Genomics 2018, 111, 921-929. [CrossRef]

17. Elshaghabee, F.M.F.; Rokana, N.; Gulhane, R.D.; Sharma, C.; Panwar, H. Bacillus As Potential Probiotics: Status, Concerns, and Future Perspectives. Front. Microbiol. 2017, 8, 1490-1505. [CrossRef]

18. Özüsağlam, M.A. Importance of Bacillus coagulans Bacterium as Probiotic in Animal Nutrition. Süleyman Demirel Üniversitesi Ziraat Fakültesi Dergisi 2010, 1, 50-57.

19. Bomko, T. King of probiotics Bacillus coagulans in modern combined probiotic preparations Laktovit forte. Ann. Mechnikov. Inst. 2016, 1, 17-37.

20. Karri, S.K.; Majeed, M.; Natarajan, S.; Sivakumar, A.; Ali, F.; Pande, A.; Majeed, S. Evaluation of anti-diarrhoeal activity of Bacillus coagulans MTCC 5856 and its effect on gastrointestinal motility in wistar rats. Int. J. Pharm. Biol. Sci. 2016, 1, 311-316.

21. Hung, A.T.; Lin, S.; Yang, T.; Chou, C.; Liu, H.; Lu, J.; Wang, B.; Chen, S.; Lien, T. Effects of Bacillus coagulans ATCC 7050 on growth performance, intestinal morphology, and microflora composition in broiler chickens. Anim. Prod. Sci. 2012, 52, 874-879. [CrossRef]

22. Shinde, T.; Vemuri, R.; Shastri, M.D.; Perera, A.P.; Tristram, S.; Stanley, R.; Eri, R. Probiotic Bacillus coagulans MTCC 5856 spores exhibit excellent in-vitro functional efficacy in simulated gastric survival, mucosal adhesion and immunomodulation. J. Funct. Foods 2019, 52, 100-108. [CrossRef]

23. Hyronimus, B.; Le Marrec, C.; Urdaci, M.C. Coagulin, a bacteriocin-like inhibitory substance produced by Bacillus coagulans I4. J. Appl. Microbiol. 1998, 85, 42-50. [CrossRef] [PubMed]

24. Donskey, C.J.; Hoyen, C.K.; Das, S.M.; Farmer, S.; Dery, M.; Bonomo, R.A. Effect of oral Bacillus coagulans administration on the density of vancomycin-resistant enterococci in the stool of colonized mice. Lett. Appl. Microbiol. 2001, 33, 84-88. [CrossRef] [PubMed]

25. Abhari, K.; Shekarforoush, S.S.; Sajedianfard, J.; Hosseinzadeh, S.; Nazifi, S. The effects of probiotic, prebiotic and synbiotic diets containing Bacillus coagulans and inulin on rat intestinal microbiota. IRAN J. Vet. Res. 2015, 16, 267-273.

26. Sarles, W.B.; Hammer, B.W. Observations on Bacillus coagulans. J. Bacteriol. 1932, 23, 301-314. [CrossRef] [PubMed]

27. Gandhi, A.B. Probiotic lactic acid bacteria. East. Pharm. 1994, 37, 43.

28. De Clerck, E.; Rodriguez-Diaz, M.; Forsyth, G.; Lebbe, L.; Logan, N.A.; DeVos, P. Polyphasic Characterization of Bacillus coagulans Strains, Illustrating Heterogeneity within this Species, and Emended Description of the Species. Syst. Appl. Microbiol. 2004, 27, 50-60. [CrossRef] 
29. Majeed, M.; Nagabhushanam, K.; Natarajan, S.; Sivakumar, A.; Eshuis-de, R.T.; Booij-Veurink, J.; de Vries, Y.P.; Ali, F. Evaluation of genetic and phenotypic consistency of Bacillus coagulans MTCC 5856: A commercial probiotic strain. World J. Microbiol. Biotechnol. 2016, 32, 60. [CrossRef]

30. Majeed, M.; Majeed, S.; Nagabhushanam, K.; Natarajan, S.; Sivakumar, A.; Ali, F. Evaluation of the stability of Bacillus coagulans MTCC 5856 during processing and storage of functional foods. Int. J. Food Sci. Technol. 2016, 51, 894-901. [CrossRef]

31. Endres, J.R.; Clewell, A.; Jade, K.A.; Farber, T.; Hauswirth, J.; Schauss, A.G. Safety assessment of a proprietary preparation of a novel Probiotic, Bacillus coagulans, as a food ingredient. Food Chem. Toxicol. 2009, 47, 1231-1238. [CrossRef] [PubMed]

32. Endres, J.R.; Qureshi, I.; Farber, T.; Hauswirth, J.; Hirka, G.; Pasics, I.; Schauss, A.G. One-year chronic oral toxicity with combined reproduction toxicity study of a novel probiotic, Bacillus coagulans, as a food ingredient. Food Chem. Toxicol. 2011, 49, 1174-1182. [CrossRef] [PubMed]

33. Wu, T.; Zhang, Y.; Lv, Y.; Li, P.; Yi, D.; Wang, L.; Zhao, D.; Chen, H.; Gong, J.; Hou, Y. Beneficial Impact and Molecular Mechanism of Bacillus coagulans on Piglets' Intestine. Int. J. Mol. Sci. 2018, 19, 2084. [CrossRef] [PubMed]

34. Cavazzoni, V. Performance of broiler chickens supplemented with Bacillus coagulans as probiotic. Br. Poult. Sci. 1998, 39, 526-529. [CrossRef]

35. Wang, Y.; Gu, Q. Effect of probiotic on growth performance and digestive enzyme activity of Arbor Acres broilers. Res. Vet. Sci. 2010, 89, 163-167. [CrossRef]

36. Zhou, X.; Wang, Y.; Gu, Q.; Li, W. Effect of dietary probiotic, Bacillus coagulans, on growth performance, chemical composition, and meat quality of Guangxi Yellow chicken. Poult. Sci. 2010, 89, 588-593. [CrossRef]

37. Wang, Y.; Gu, Q. Effect of probiotics on white shrimp (Penaeus vannamei) growth performance and immune response. Mar. Biol. Res. 2010, 6, 327-332. [CrossRef]

38. Wang, Y. Use of probiotics Bacillus coagulans, Rhodopseudomonas palustris and Lactobacillus acidophilus as growth promoters in grass carp (Ctenopharyngodon idella) fingerlings. Aquac. Nutr. 2011, 17, e372-e378. [CrossRef]

39. Arunachalam, K.D. Role of Bifidobacteria in nutrition, medicine and technology. Nutr. Res. 1999, 10, 1559-1597. [CrossRef]

40. Xuan, Z.N.; Kim, J.D.; Heo, K.N.; Jung, H.J.; Lee, J.H.; Han, Y.K.; Kim, Y.Y.; Han, I.K. Study on the Development of a Probiotics Complex for Weaned Pigs. Asian Australas J. Anim. 2001, 14, 1425-1428. [CrossRef]

41. LeBlanc, J.G.; Chain, F.; Martín, R.; Bermúdez-Humarán, L.G.; Courau, S.; Langella, P. Beneficial effects on host energy metabolism of short-chain fatty acids and vitamins produced by commensal and probiotic bacteria. Microb. Cell Fact. 2017, 16, 79-89. [CrossRef] [PubMed]

42. Maathuis, A.; Keller, D.; Farmer, S. Survival and metabolic activity of the GanedenBC30 strain of Bacillus coagulans in a dynamicin vitro model of the stomach and small intestine. Benef. Microbes 2010, 1, 31-36. [CrossRef] [PubMed]

43. Honda, H.; Gibson, G.R.; Farmer, S.; Keller, D.; McCartney, A.L. Use of a continuous culture fermentation system to investigate the effect of GanedenBC30 (Bacillus coagulans GBI-30, 6086) supplementation on pathogen survival in the human gut microbiota. Anaerobe 2011, 17, 36-42. [CrossRef] [PubMed]

44. Cartman, S.T.; La Ragione, R.M.; Woodward, M.J. Bacillus subtilis Spores Germinate in the Chicken Gastrointestinal Tract. Appl. Environ. Microb. 2008, 74, 5254-5258. [CrossRef] [PubMed]

45. Gu, S.; Zhao, L.; Wu, Y.; Li, S.; Sun, J.; Huang, J.; Li, D. Potential probiotic attributes of a new strain of Bacillus coagulans CGMCC 9951 isolated from healthy piglet feces. World J. Microbiol. Biotechnol. 2015, 31, 851-863. [CrossRef]

46. Zhao, R.; Zhao, R.; Tu, Y.; Zhang, X.; Deng, L.; Chen, X. A novel $\alpha$-galactosidase from the thermophilic probiotic Bacillus coagulans with remarkable protease-resistance and high hydrolytic activity. PLoS ONE 2018, 13, e0197067. [CrossRef]

47. Kimmel, M.; Keller, D.; Farmer, S.; Warrino, D.E. A controlled clinical trial to evaluate the effect of GanedenBC(30) on immunological markers. Methods Find. Exp. Clin. Pharmacol. 2010, 32, 129-132. [CrossRef]

48. Jäger, R.; Purpura, M.; Farmer, S.; Cash, H.A.; Keller, D. Probiotic Bacillus coagulans GBI-30, 6086 Improves Protein Absorption and Utilization. Probiotics Antimicrob. Proteins 2018, 10, 611-615. [CrossRef] 
49. Keller, D.; Van Dinter, R.; Cash, H.; Farmer, S.; Venema, K. Bacillus coagulans GBI-30, 6086 increases plant protein digestion in a dynamic, computer-controlledin vitro model of the small intestine (TIM-1). Benef. Microbes 2017, 8, 491-496. [CrossRef]

50. Sarao, L.K.; Arora, M. Probiotics, prebiotics, and microencapsulation: A review. Crit. Rev. Food Sci. 2015, 57, 344-371. [CrossRef]

51. Majeed, M.; Majeed, S.; Nagabhushanam, K.; Arumugam, S.; Natarajan, S.; Beede, K.; Ali, F. Galactomannan from Trigonella foenum-graecum L. seed: Prebiotic application and its fermentation by the probiotic Bacillus coagulans strain MTCC 5856. Food Sci. Nutr. 2018, 6, 666-673. [CrossRef] [PubMed]

52. Nyangale, E.P.; Farmer, S.; Keller, D.; Chernoff, D.; Gibson, G.R. Effect of prebiotics on the fecal microbiota of elderly volunteers after dietary supplementation of Bacillus coagulans GBI-30, 6086. Anaerobe 2014, 30, 75-81. [CrossRef] [PubMed]

53. Ruemmele, F.M.; Bier, D.; Marteau, P.; Rechkemmer, G.; Bourdet-Sicard, R.; Walker, W.A.; Goulet, O. Clinical Evidence for Immunomodulatory Effects of Probiotic Bacteria. J. Pediatric Gastroenterol. Nutr. 2009, 48, 126-141. [CrossRef]

54. Jensen, G.S.; Benson, K.F.; Carter, S.G.; Endres, J.R. GanedenBC30 $30^{\mathrm{TM}}$ cell wall and metabolites: Anti-inflammatory and immune modulating effects in vitro. BMC Immunol. 2010, 11, 15. [CrossRef]

55. Lebeer, S.; Vanderleyden, J.; De Keersmaecker, S.C.J. Host interactions of probiotic bacterial surface molecules: Comparison with commensals and pathogens. Nat. Rev. Microbiol. 2010, 8, 171-184. [CrossRef] [PubMed]

56. Dominguez-Bello, M.G.; Blaser, M.J. Do you have a probiotic in your future? Microbes Infect. 2008, 10, 1072-1076. [CrossRef]

57. Ng, S.C.; Hart, A.L.; Kamm, M.A.; Stagg, A.J.; Knight, S.C. Mechanisms of action of probiotics: Recent advances. Inflamm. Bowel Dis. 2009, 15, 300-310. [CrossRef]

58. Jensen, G.; Cash, H.; Farmer, S.; Keller, D. Inactivated probiotic Bacillus coagulans GBI-30 induces complex immune activating, anti-inflammatory, and regenerative markers in vitro. J. Inflamm. Res. 2017, 10, 107-117. [CrossRef]

59. Hao, Q.; Dong, B.R.; Wu, T. Probiotics for preventing acute upper respiratory tract infections. Cochrane Database Syst. Rev. 2011. [CrossRef]

60. Akira, S.; Takeda, K. Toll-like receptor signalling. Nat. Rev. Immunol. 2004, 4, 499-511. [CrossRef]

61. Schwandner, R.; Dziarski, R.; Wesche, H.; Rothe, M.; Kirschning, C.J. Peptidoglycan- and lipoteichoic acid-induced cell activation is mediated by toll-like receptor 2. J. Biol. Chem. 1999, 274, 17406-17409. [CrossRef] [PubMed]

62. Forrester, I.T.; Wicken, A.J. The Chemical Composition of the Cell Walls of Some Thermophilic Bacilli. J. Gen. Microbiol. 1966, 42, 147-154. [CrossRef] [PubMed]

63. Kang, S.; Sim, J.; Yun, C.; Han, S.H. Lipoteichoic acids as a major virulence factor causing inflammatory responses via Toll-like receptor 2. Arch. Pharm. Res. 2016, 39, 1519-1529. [CrossRef] [PubMed]

64. Frei, R.; Akdis, M.; Mahony, L. Prebiotics, probiotics, synbiotics, and the immune system. Curr. Opin. Gastroenterol. 2015, 31, 153-158. [CrossRef]

65. Habil, N.; Abate, W.; Beal, J.; Foey, A.D. Heat-killed probiotic bacteria differentially regulate colonic epithelial cell production of human $\beta$-defensin-2: Dependence on inflammatory cytokines. Benef. Microbes 2014, 5, 483-495. [CrossRef]

66. Benson, K.F. Probiotic metabolites from Bacillus coagulans GanedenBC $30^{\mathrm{TM}}$ support maturation of antigen-presenting cellsin vitro. World J. Gastroenterol. 2012, 18, 1875. [CrossRef]

67. Sekirov, I.; Russell, S.L.; Antunes, L.C.M.; Finlay, B.B. Gut Microbiota in Health and Disease. Physiol. Rev. 2010, 90, 859-904. [CrossRef]

68. Jones, R.M.; Neish, A.S. Redox signaling mediated by the gut microbiota. Free Radic. Biol. Med. 2017, 105, 41-47. [CrossRef]

69. Schieber, M.; Chandel, N.S. ROS Function in Redox Signaling and Oxidative Stress. Curr. Biol. 2014, 24, R453-R462. [CrossRef]

70. Mouthuy, P.; Snelling, S.J.B.; Dakin, S.G.; Milković, L.; Gašparović, A.Č.; Carr, A.J.; Žarković, N. Biocompatibility of implantable materials: An oxidative stress viewpoint. Biomaterials 2016, 109, 55-68. [CrossRef] 
71. Bermejo-Nogales, A.; Fernández, M.; Fernández-Cruz, M.L.; Navas, J.M. Effects of a silver nanomaterial on cellular organelles and time course of oxidative stress in a fish cell line (PLHC-1). Comp. Biochem. Physiol. Part C Toxicol. Pharmacol. 2016, 190, 54-65. [CrossRef] [PubMed]

72. Chauhan, R.; Sudhakaran Vasanthakumari, A.; Panwar, H.; Mallapa, R.H.; Duary, R.K.; Batish, V.K.; Grover, S. Amelioration of Colitis in Mouse Model by Exploring Antioxidative Potentials of an Indigenous Probiotic Strain of Lactobacillus fermentum Lf1. Biomed. Res. Int. 2014, 2014, 1-12. [CrossRef] [PubMed]

73. Pompei, A.; Cordisco, L.; Amaretti, A.; Zanoni, S.; Matteuzzi, D.; Rossi, M. Folate Production by Bifidobacteria as a Potential Probiotic Property. Appl. Environ. Microb. 2006, 73, 179-185. [CrossRef]

74. Stilling, R.M.; Dinan, T.G.; Cryan, J.F. Microbial genes, brain \& behaviour-epigenetic regulation of the gut-brain axis. Genes Brain Behav. 2014, 13, 69-86.

75. Yu, Y.; Wang, C.; Wang, A.; Yang, W.; Lv, F.; Liu, F.; Liu, B.; Sun, C. Effects of various feeding patterns of Bacillus coagulans on growth performance, antioxidant response and Nrf2-Keap1 signaling pathway in juvenile gibel carp (Carassius auratus gibelio). Fish Shellfish Immunol. 2018, 73, 75-83. [CrossRef] [PubMed]

76. Majlesi, M.; Shekarforoush, S.S.; Ghaisari, H.R.; Nazifi, S.; Sajedianfard, J.; Eskandari, M.H. Effect of Probiotic Bacillus coagulans and Lactobacillus plantarum on Alleviation of Mercury Toxicity in Rat. Probiotics Antimicro 2017, 9, 300-309. [CrossRef]

77. Jafarpour, D.; Shekarforoush, S.S.; Ghaisari, H.R.; Nazifi, S.; Sajedianfard, J.; Eskandari, M.H. Protective effects of synbiotic diets of Bacillus coagulans, Lactobacillus plantarum and inulin against acute cadmium toxicity in rats. BMC Complement. Altern. Med. 2017, 17, 291. [CrossRef]

78. Farmand, F.; Ehdaie, A.; Roberts, C.K.; Sindhu, R.K. Lead-induced dysregulation of superoxide dismutases, catalase, glutathione peroxidase, and guanylate cyclase. Environ. Res. 2005, 98, 33-39. [CrossRef]

79. Gavrilescu, M. Removal of Heavy Metals from the Environment by Biosorption. Eng. Life Sci. 2004, 4, 219-232. [CrossRef]

(C) 2020 by the authors. Licensee MDPI, Basel, Switzerland. This article is an open access article distributed under the terms and conditions of the Creative Commons Attribution (CC BY) license (http://creativecommons.org/licenses/by/4.0/). 